www.nature.com/ja

\title{
NMR study of peplomycin in aqueous solution. Assignment of resonances by means of two-dimensional spectroscopy
}

\author{
Teresa E Lehmann ${ }^{1}$, Yang $\mathrm{Li}^{1}$ and Geoffrey S Armstrong ${ }^{2}$ \\ ${ }^{1} \mathrm{H}$-NMR spectra of peplomycin (PEP) recorded at 400 and, for the first time, $900 \mathrm{MHz}$ at $2{ }^{\circ} \mathrm{C}$ were examined. All the spin \\ systems in the PEP molecule were identified through 2D NMR spectroscopy. The use of NMR spectroscopy allowed the \\ unambiguous assignment of 62 protons, generating 47 non-exchangeable and 15 exchangeable signals. The analysis of the \\ signals observed in 2D-NOE spectra indicates that PEP exhibits an extended conformation at $2{ }^{\circ} \mathrm{C}$. A comparison between the \\ solution conformation of apo-PEP and the solution structure of HOO-Co(III)-PEP indicates that the overall structure of apo-PEP \\ is extended in solution, but exhibiting a conformation of the bithiazole (B)-sulfonium (S) unit similar to that of HOO-Co(III)-PEP. \\ The present investigation represents the initial stage of an NMR study of the solution conformation and dynamics of PEP, its \\ derivatives, its metal complexes and the interactions of metallo-PEPs with their target DNA.
}

The Journal of Antibiotics (2011) 64, 309-316; doi:10.1038/ja.2010.163; published online 16 February 2011

Keywords: antibiotic; NMR; peplomycin; spectroscopy

\section{INTRODUCTION}

Bleomycins (BLMs) (Figure 1) are antitumor agents that are isolated from Streptomyces verticillus. ${ }^{1}$ Clinically, BLMs are employed for the treatment of squamous cell carcinomas, ${ }^{2}$ non-Hodgkin's lymphomas, ${ }^{3}$ testicular carcinomas ${ }^{4}$ and ovarian cancer. ${ }^{5}$ The drug acts as an antitumor agent by virtue of the ability of a metal complex of the antibiotic to cleave DNA. ${ }^{6}$ Although elaborated by $S$. verticillus as a copper chelate, ${ }^{1}$ it is an iron chelate of BLM that has been reported to coordinate and reduce oxygen, thus producing the 'active complex' of BLM. ${ }^{7}$

In spite of the efficacy of BLM as an anticancer drug, patients under BLM regimes frequently develop pulmonary toxicity, which is attributed to cell membrane damage promoted by the drug. ${ }^{89}$ This negative effect, together with others such as hypotension and renal and hepatic toxicities, limit the use of the drug in patients and prompt the development of BLM analogues with the same or increased clinical efficiency. About 300 derivatives of BLM have been prepared and screened to this end, ${ }^{10}$ with peplomycin (PEP) (Figure 1) exhibiting stronger activity and less pulmonary toxicity than BLM. ${ }^{11,12}$ PEP and BLM comprise the metal binding domain, the bithiazole-C-terminus group and the gulose-mannose group, which are tethered to each other as shown in Figure 1. It has been established that BLM and its congener PEP bind iron (II) through their metal-binding domain and activate oxygen to cleave DNA, to which the bithiazole group intercalates. ${ }^{7,13-15}$ To achieve a fundamental understanding of the molecular mechanism of PEP activity, knowledge of the three-dimensional solution structure of this drug, its metal complexes and complexes of the latter with DNA are required. Additionally, this knowledge could also help to guide the synthesis of less toxic BLM and/or PEP analogues with a higher therapeutic action.

The method of choice for studying molecular structure is a high resolution NMR. Some important investigations of metallo-PEPs have been undertaken; ${ }^{16-18}$ however, the complete assignment of the proton spectrum of PEP is lacking from the scientific literature. The present investigation represents the initial stage of an NMR study of the solution conformation and dynamics of PEP, its derivatives, its metal complexes and the interactions of metallo-PEPs with their target DNA. Prerequisite to such a project is the identification of spectral resonances with specific nuclei of the antibiotic. In the present paper, complete assignment of the ${ }^{1} \mathrm{H}-\mathrm{NMR}$ spectrum of PEP is presented. These results were obtained at 400 and $900 \mathrm{MHz}$ using one- and twodimensional spectroscopies.

\section{MATERIALS AND METHODS}

Sample preparation

PEP was a generous gift of Nippon Kayaku Co., Ltd (Tokyo, Japan). PEP $(3 \mu \mathrm{mol})$ lyophilized three times from $\mathrm{D}_{2} \mathrm{O}$ was dissolved in $0.6 \mathrm{ml}$ of $\mathrm{D}_{2} \mathrm{O}$ (99.9\% D; Sigma). The $\mathrm{pH}$ (meter reading uncorrected for deuterium isotope effect) was adjusted to 6.5 with $0.1 \mathrm{~mm} \mathrm{NaOD}$ solution in $\mathrm{D}_{2} \mathrm{O}$. A PEP sample in $90 \% \mathrm{H}_{2} \mathrm{O} / 10 \% \mathrm{D}_{2} \mathrm{O}$ was prepared by an analogous procedure. 


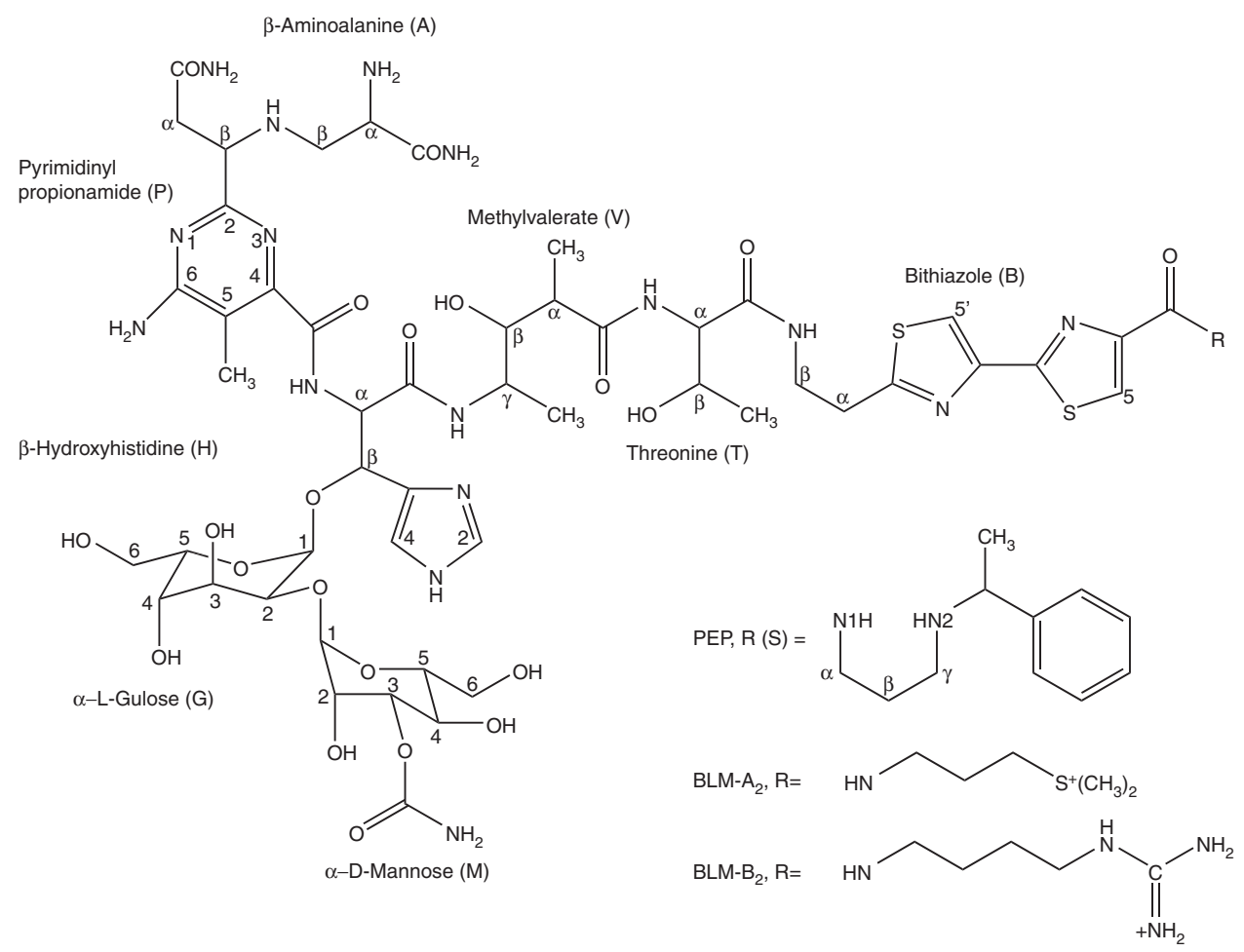

Figure 1 Structures of PEP and $B L M-A_{2}$ and $-B_{2}$.

A PEP sample in 100\% dimethyl sulfoxide-d6 (DMSO-d6), to examine some of the $\mathrm{NH}$ and $\mathrm{NH}_{2}$ signals in PEP, was obtained by dissolving $3 \mu \mathrm{mol}$ PEP in $600 \mu \mathrm{l}$ of $100 \%$ DMSO-d6.

\section{NMR Spectra}

NMR experiments in $\mathrm{H}_{2} \mathrm{O}$ and $\mathrm{D}_{2} \mathrm{O}$ were performed at 400 and $900 \mathrm{MHz}$ on a Bruker DXR400 system (Bruker BioSpin Corp., Billerica, MA, USA) and a Varian NMR Direct Drive 900 system (Agilent Technologies, Inc., Santa Clara, CA, USA) equipped with a cryogenically cooled probe and referenced to HDO as the internal standard. NMR experiments in DMSO were all collected at $400 \mathrm{MHz}$. Spectra were Fourier transformed using Lorentzian-to-Gaussian weighting and phase-shifted sine-bell window functions. Processing and analysis of the NMR data were performed on a PC Core 2 Duo workstation (Dell, Chicago, IL, USA) using NMRPipe ${ }^{19}$ and NMRView ${ }^{20}$ software.

For the TOCSY ${ }^{21,22}$ and NOESY ${ }^{23}$ spectra collected at $900 \mathrm{MHz}$ and $2{ }^{\circ} \mathrm{C}$, soft flipback pulses were used to minimize water excitation. Mixing times were 40 and $150 \mathrm{~ms}$, with 16384 and 900 points collected in the direct and indirect dimensions, respectively. An $8 \mathrm{kHz}$ DIPSI mixing sequence was used in the TOCSY. Spectral widths were 14.5 and $8.4 \mathrm{kHz}$.

TOCSY spectra in DMSO were collected at $400 \mathrm{MHz}$ with the temperature set at $2{ }^{\circ} \mathrm{C}$, mixing time of $40 \mathrm{~ms}$ and a $25 \mathrm{kHz}$ MLEV- 17 mixing sequence. Spectral widths were 12 p.p.m. in both dimensions and $512 t_{1}$ points were acquired with 2048 complex points for each free induction decay (FID). The number of scans for a $t_{1}$ point was 32. Spectra were Fourier transformed using Lorentzian-toGaussian weighting and phase-shifted sine-bell window functions.

Spin-echo correlated spectroscopy (SECSY ${ }^{24,25}$ experiments were performed at $2{ }^{\circ} \mathrm{C}$ in $\mathrm{D}_{2} \mathrm{O}$. Before the standard SECSY pulse sequence, during the relaxation delay period $(2.5 \mathrm{~s})$, the HDO resonance was selectively irradiated $(64 \mathrm{db})$. Quadrature detection was used in both directions. For each value of $t_{1}$, 32 FIDs (2048 data points, acquisition time $0.314 \mathrm{~s}$ ) were acquired. Before FT, the FIDs were multiplied with a sine-bell window function in both directions. Spectra were calculated in absolute value mode.

$\operatorname{COSY}^{26}$ spectra were recorded at $400 \mathrm{MHz}$ in $\mathrm{D}_{2} \mathrm{O}$ at $25^{\circ} \mathrm{C}$, with a data matrix of $2048 \times 512\left(\mathrm{t}_{1}\right)$ complex pairs. Before the standard COSY pulse sequence, during the relaxation delay period $(2.5 \mathrm{~s})$, the HDO resonance was selectively irradiated $(64 \mathrm{db})$. The spectral width was $6000 \mathrm{~Hz}$ in both dimensions. FIDs were multiplied with a sine-bell window function in both directions. Spectra were calculated in absolute value mode.

${ }^{1} \mathrm{H}$-detected $\mathrm{HMQC}^{27}\left(J_{\mathrm{CH}}\right.$ set at $145 \mathrm{~Hz}$ ) were recorded at $900 \mathrm{MHz}$ and $2{ }^{\circ} \mathrm{C}$, with a spectral width in the indirect dimension of $11300 \mathrm{~Hz}$ and 190 points.

\section{Structural explorations}

The starting structure for apo-PEP was generated from the structure for HOO-Co(III)-PEP determined by Caceres-Cortes et al. ${ }^{16}$ (PDB ID 1AO4) by removing the HOO-Co(III) segment. All calculations were carried out with Discover Studio (Accelrys, San Diego, CA, USA) on an Intel Xenon workstation (Dell). Aqueous simulations were carried out using a 10 solvent shell. The nonbonded van der Waals interaction was cut off at $25 \AA$ for the solvent system. The distance-dependent dielectric constant algorithm was used. Molecular dynamics calculations used the Verlet velocity algorithm with $0.01 \mathrm{ps}$ time step and scaling every 10 steps. The calculation protocol used to explore the structure of apo-PEP is similar to that employed with $\mathrm{Cu}(\mathrm{I}) \mathrm{BLM} .^{28} \mathrm{~A} 10 \AA$ solvent shell was created around the apo-PEP. The water molecules were minimized with group-based cutoff, while holding apo-PEP fixed. Then the water molecules were fixed and apo-PEP was minimized with no constraints using the cell multipole method. Apo-PEP was first energy minimized without constraints by the steepest descent method, followed by conjugate gradient minimization to an r.m.s. gradient of $<0.1$. As only trivial NOEs were detected for apo-PEP, the structure resulting from minimization was used in molecular dynamics-simulated annealing. Five calculations were run with different starting velocities. Each calculation consisted of the following steps: (1) Heat and equilibrate the system from 5 to $1000 \mathrm{~K}$ over 10 ps in $10 \mathrm{~K}$ increments, with velocities assigned every 0.001 ps. (2) High-temperature equilibration for 6 ps. (3) Slow cool down to $300 \mathrm{~K}$ over a period of 7 ps. (4) Final molecular dynamics run for $15 \mathrm{ps}$. The final structure for each iteration was generated by mass-weighted r.m.s., fitting and averaging the coordinates from the last 5 ps of the trajectory, followed by energy minimization. The overall final structure was obtained from the minimized average of the five average structures. All energy minimizations used the CHARMM (Accelrys) force field. 


\section{RESULTS}

NMR assignments

Methylvalerate $(V)$ and threonine $(T)$ protons. The ${ }^{1} \mathrm{H}$ signals elicited by these moieties were assigned using their methyl groups as a starting point. The methyl signal at 1.043 p.p.m. is connected via TOCSY cross peaks (Figure 2) to two features at 4.029 and 4.150 p.p.m., which are in turn connected to each other. This pattern of connectivities is indicative of a $\mathrm{CH}_{3}-\mathrm{CH}-\mathrm{CH}$ spin system. The only network of coupled spins of this type in the PEP molecule is that exhibited by T.

The V moiety exhibits a more complicated spin system $\left(\mathrm{CH}_{3}-\mathrm{CH}-\right.$ $\mathrm{CH}-\mathrm{CH}-\mathrm{CH}_{3}$ ), which can be traced in the TOCSY spectrum in Figure 2. In this figure, the signals at 1.066 p.p.m. $\left(\mathrm{CH}_{3}\right)$ are connected to a feature at 2.426 p.p.m. $(\mathrm{CH})$. The latter is in turn connected to two other signals at 3.677 p.p.m. $(\mathrm{CH})$ and 3.811 p.p.m. $(\mathrm{CH})$, which are correlated to each other and to another $\mathrm{CH}_{3}$ signal at 1.075 p.p.m. Three-bond SECSY cross peaks (data not shown) were observed between the pairs $\mathrm{C}^{\alpha} \mathrm{CH}_{3}-\mathrm{C}^{\alpha} \mathrm{H}(1.066,2.426)$ p.p.m., $\mathrm{C}^{\alpha} \mathrm{H}-\mathrm{C}^{\beta} \mathrm{H}$ (2.426, 3.677) p.p.m., $\mathrm{C}^{\beta} \mathrm{H}-\mathrm{C}^{\gamma} \mathrm{H}(3.677,3.811)$ p.p.m. and $\mathrm{C}^{\gamma} \mathrm{H}-$ $\mathrm{C}^{\gamma} \mathrm{CH}_{3}(3.811,1.075)$ p.p.m., which allowed the identification of the different protons in the $\mathrm{V}$ residue.

$\beta$-Hydroxyhistidine $(H)$ protons. The $\alpha$ and $\beta$ protons of the $\mathrm{H}$ residue were assigned on the basis of their low field positions $\mathrm{HC}^{\alpha} \mathrm{H}$ (5.020 p.p.m.) and $\mathrm{HC}^{\beta} \mathrm{H}$ (5.203 p.p.m.) (Figure 3 inset 1) typical of these protons in the BLM family. ${ }^{29}$ There are no additional connectivities between the $\mathrm{HC}^{\alpha} \mathrm{H}$ and $\mathrm{HC}^{\beta} \mathrm{H}$ signals and other aliphatic resonances on the spectra, as is expected on the basis of the molecular structure. The two aromatic ring protons of the $\mathrm{H}$ moiety are readily identified in the TOCSY spectrum of PEP collected in $\mathrm{D}_{2} \mathrm{O}$ (Figure 3). The signals generated by these protons are TOCSY-connected and are assigned to positions 7.745 p.p.m. (HC2H) and 7.207 p.p.m. (HC4H).

Bithiazole (B) and sulfonium (S) protons. The resonances elicited by the $S$ protons are easily identified because of the nature of the spin system exhibited by this moiety $\left(\mathrm{CH}_{2}-\mathrm{CH}_{2}-\mathrm{CH}_{2}\right)$. In the TOCSY spectrum collected at $2{ }^{\circ} \mathrm{C}$, the protons display a very rich pattern of connectivities (Figure 2). The signals at 1.838 and 1.936 p.p.m., elicited by a $\mathrm{CH}_{2}$ group, are connected to two other $\mathrm{CH}_{2}$ sets located at $(2.773,2.887)$ and $(3.325,3.392)$ p.p.m.. These signals are also correlated in the same way in COSY spectra (data not shown). The pairs $(2.773,2.887)$ and $(3.325,3.392)$ p.p.m. are also connected to each other. These facts allow the assignments of the aforementioned NMR features to the $\mathrm{C}^{\alpha} \mathrm{H}_{2}(3.325,3.392)$ p.p.m., $\mathrm{C}^{\beta} \mathrm{H}_{2}(1.838,1.936)$ p.p.m. and $\mathrm{C}^{\gamma} \mathrm{H}_{2}(2.773,2.887)$ p.p.m. protons of the $\mathrm{S}$ moiety. Another set of COSY and TOCSY correlated features located at 1.592 p.p.m. $\left(\mathrm{CH}_{3}\right)$ and 4.333 p.p.m. $(\mathrm{CH})$ are also assigned to protons of the $\mathrm{S}$ residue. Having assigned the methyl resonances of the $\mathrm{T}$ and $\mathrm{V}$ moieties, there are only two candidates left for these features, namely $\mathrm{SC}^{\gamma} \mathrm{CH}_{3}$ and $\mathrm{SC}^{\gamma} \mathrm{H}$, respectively. The phenyl resonances were assigned via HMQC collected at $2{ }^{\circ} \mathrm{C}$ (Figure 3 inset 2). Assignments of the ${ }^{13} \mathrm{C}$ signals of PEP performed by Naganawa et al. ${ }^{30}$ indicate that $\mathrm{BC} 5 \mathrm{H}, \mathrm{BC} 5^{\prime} \mathrm{H}, \mathrm{HC} 2 \mathrm{H}, \mathrm{HC} 4 \mathrm{H}, \mathrm{SC} 2 \mathrm{H}$ and $\mathrm{SC} 6 \mathrm{H}$ (ortho); $\mathrm{SC} 3 \mathrm{H}$ and $\mathrm{SC} 5 \mathrm{H}$ (meta); and $\mathrm{SC} 4 \mathrm{H}$ (para) are the non-exchangeable protons, exhibiting the largest chemical shifts in the PEP spectrum. A relative signal arrangement of the resonances for these protons, similar to that found by Naganawa et al., allowed us to locate the ortho, meta and para protons of the sulfonium unit at 7.334, 7.239 and 7.193 p.p.m., respectively.

The COSY-and TOCSY-(Figure 2) coupled NMR features located at (3.169, 3.198) and 3.550 p.p.m. are assigned to $\mathrm{BC}^{\alpha} \mathrm{H}_{2}$ and $\mathrm{BC}^{\beta} \mathrm{H}_{2}$, respectively. These assignments were made on the basis of overlap of the $\mathrm{BNH}$ resonance with the $\mathrm{VNH}$ signal (vide supra), which is typically observed in NMR spectra of the BLM family. ${ }^{29}$

Having assigned to aromatic ring proton signals of the histidyl unit (vide infra), the remaining aromatic features at 8.065 and 7.891 p.p.m. (Figure 3) are attributed to the ring protons $\mathrm{BC} 5 \mathrm{H}$ and $\mathrm{BC}^{\prime} \mathrm{H}$, respectively (Figures 3 ).

Gulose ( $G$ ) and mannose (M) protons. The sets of connectivities displayed by the $\mathrm{G}$ and $\mathrm{M}$ moieties in the BLM family start with the anomeric protons $\mathrm{GH} 1$ and $\mathrm{MH1}$, located at 5.230 and 4.932 p.p.m.,

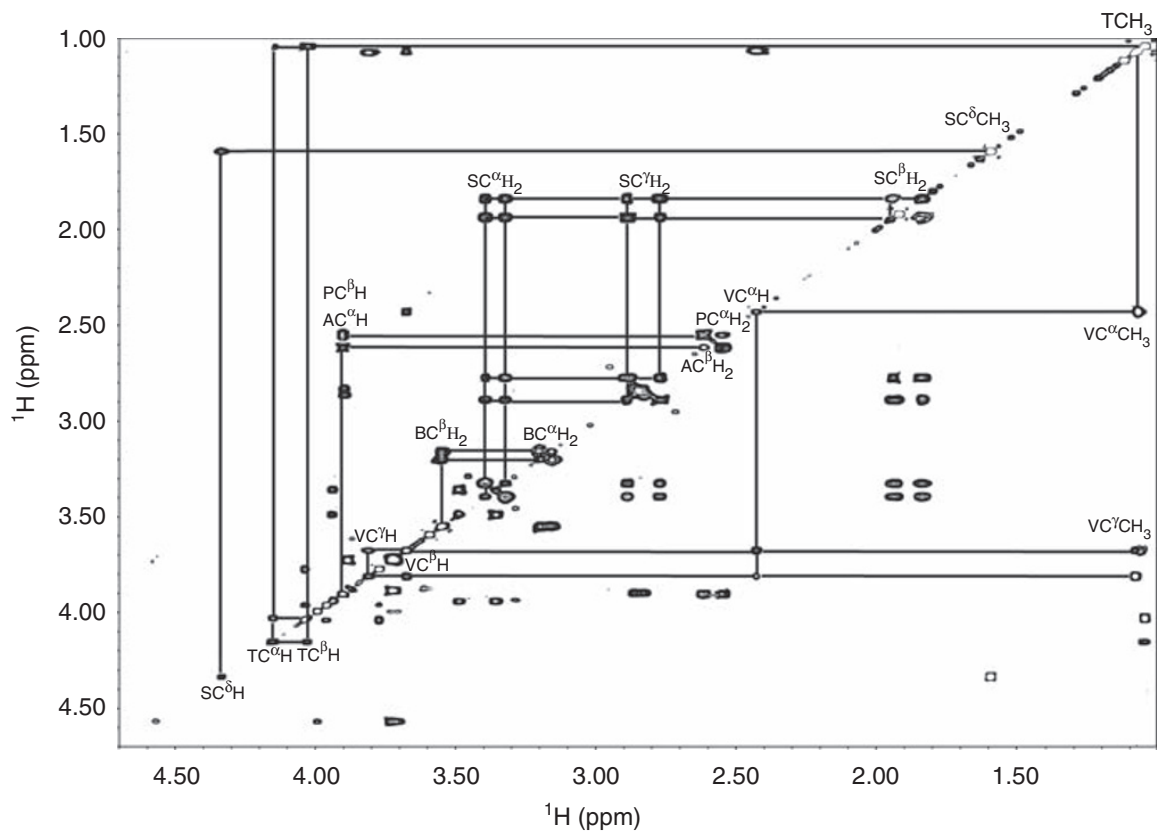

Figure 2 The $1.00-4.70$ p.p.m. region of the $900 \mathrm{MHz}$ TOCSY spectrum ( $40 \mathrm{~ms}$ mixing time) at $2{ }^{\circ} \mathrm{C}$, pH 6.5 of a $5 \mathrm{~mm} \mathrm{PEP} \mathrm{sample} 90 \% \mathrm{H}_{2} \mathrm{O} / 10 \% \mathrm{D}_{2} \mathrm{O}$ showing the assignments of the $T\left(C^{\alpha} \mathrm{H}, \mathrm{C}^{\beta} \mathrm{H}, \mathrm{CH}_{3}\right), \mathrm{A}\left(\mathrm{C}^{\alpha} \mathrm{H}, \mathrm{C}^{\beta} \mathrm{H}_{2}\right), \mathrm{P}\left(\mathrm{C}^{\beta} \mathrm{H}, \mathrm{C}^{\alpha} \mathrm{H}_{2}\right), \mathrm{V}\left(\mathrm{C}^{\alpha} \mathrm{H}, \mathrm{C}^{a} \mathrm{H}, \mathrm{C}^{\gamma} \mathrm{H}, \mathrm{C}^{\alpha} \mathrm{CH}_{3}, \mathrm{C}^{\gamma} \mathrm{CH}_{3}\right), \mathrm{S}\left(\mathrm{C}^{\alpha} \mathrm{H}_{2}, \mathrm{C}^{\beta} \mathrm{H}_{2}, \mathrm{C}^{\gamma} \mathrm{H}_{2}, \mathrm{C}^{\delta} \mathrm{H}, \mathrm{C}^{\delta} \mathrm{CH}_{3}\right)$ and $\mathrm{B}\left(\mathrm{C}^{\alpha} \mathrm{H}_{2}, \mathrm{C}^{\beta} \mathrm{H}_{2}\right)$ protons. 


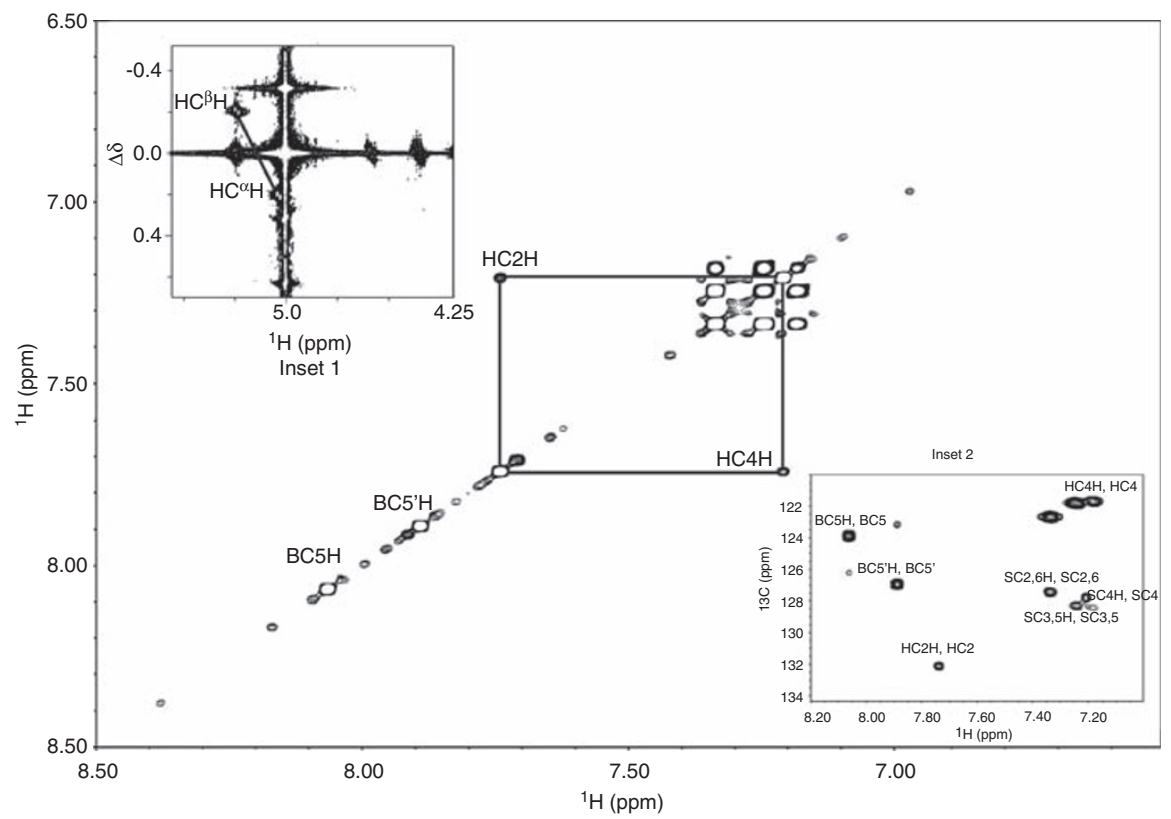

Figure 3 The $6.50-8.50$ p.p.m. region of the $900 \mathrm{MHz}$ TOCSY spectrum ( $40 \mathrm{~ms}$ mixing time) at $2{ }^{\circ} \mathrm{C}, \mathrm{pH} 6.5$ of a $5 \mathrm{~mm}$ PEP sample $100 \% \mathrm{D}_{2} \mathrm{O}$ showing the assignments of the $\mathrm{H}(\mathrm{C} 2 \mathrm{H}, \mathrm{C} 4 \mathrm{H})$, and $\mathrm{BC} 5 \mathrm{H}$ and $\mathrm{BC} 5^{\prime} \mathrm{H}$ protons. Inset 1: the $4.25-5.60$ p.p.m. region of the $400 \mathrm{MHz} S E C S Y$ spectrum at $2{ }^{\circ} \mathrm{C}$, pH 6.5 of a $5 \mathrm{~mm}$ PEP sample $100 \% \mathrm{D}_{2} \mathrm{O}$ showing the assignments of the $\mathrm{H}\left(\mathrm{C}^{\alpha} \mathrm{H}, \mathrm{C}^{\beta} \mathrm{H}\right)$ protons. Inset 2: The ${ }^{1} \mathrm{H} 7.00-8.20$ p.p.m., ${ }^{13} \mathrm{C} 120-134.5$ p.p.m. region of the $900 \mathrm{MHz} H M Q C$ spectrum at $2^{\circ} \mathrm{C}, \mathrm{pH} 6.5$ of a $5 \mathrm{~mm}$ PEP sample $100 \% \mathrm{D}_{2} \mathrm{O}$ showing the assignments of the $\mathrm{B}\left(\mathrm{C} 5 \mathrm{H}, \mathrm{C} 5^{\prime} \mathrm{H}\right), \mathrm{H}(\mathrm{C} 2 \mathrm{H}, \mathrm{C} 4 \mathrm{H})$ and $\mathrm{S}(\mathrm{C} 2,6 \mathrm{H}, \mathrm{C} 3,5 \mathrm{H}, \mathrm{C} 4 \mathrm{H})$ protons and their directly attached carbons.

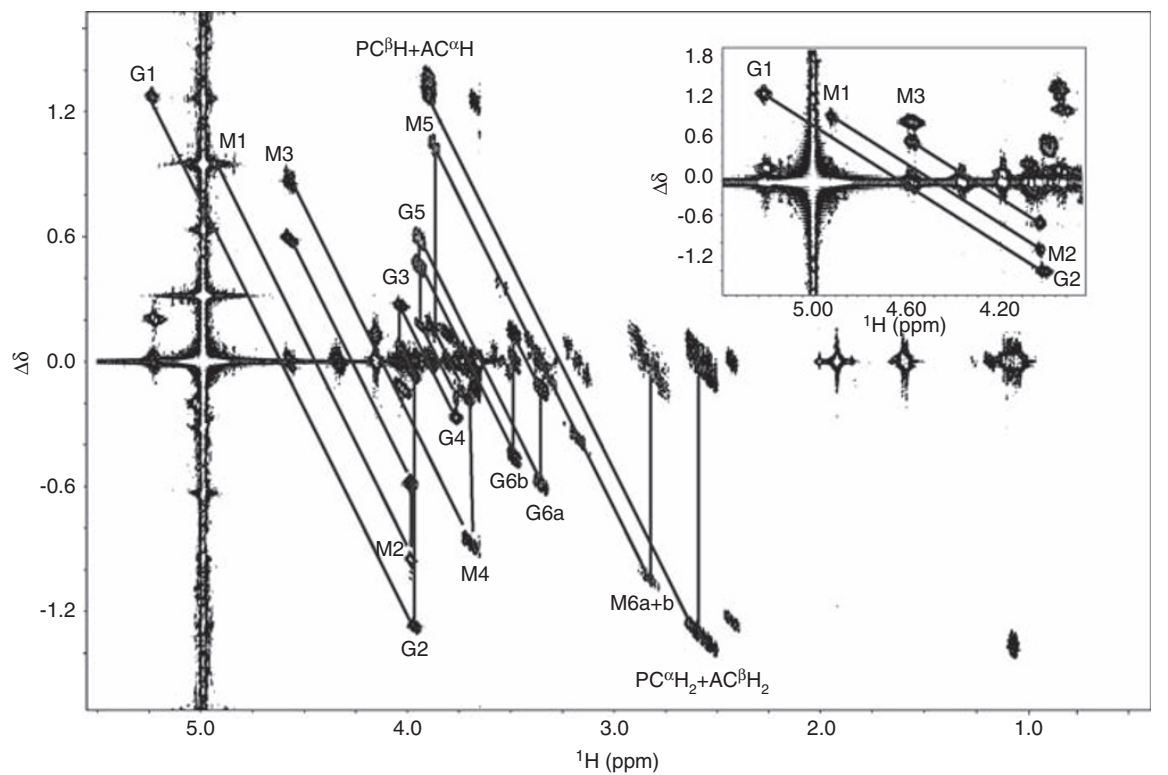

Figure 4 The ${ }^{1} \mathrm{H} 0.45-5.55$ p.p.m., region of the $400 \mathrm{MHz}$ SECSY spectrum at $2^{\circ} \mathrm{C}$, pH 6.5 of a $5 \mathrm{~mm}$ PEP sample $100 \% \mathrm{D}_{2} \mathrm{O}$ tracing the connectivities displayed by the $G$ and $M$ residues in PEP.

respectively (Figure 4). These two signals, and the ones assigned to $\mathrm{HC}^{\beta} \mathrm{H}$ and $\mathrm{HC}^{\alpha} \mathrm{H}$ protons, are the only ones found in the aliphatic region of the PEP spectrum, downfield of the water resonance and they form the starting points in the two networks of connectivities displayed by the $\mathrm{G}$ and $\mathrm{M}$ residues. Both the sugar moieties display $\mathrm{CH}-\mathrm{CH}-\mathrm{CH}-\mathrm{CH}-\mathrm{CH}-\mathrm{CH}_{2}$ spin systems. The identification of the two identical networks of connectivities, as belonging to either the $\mathrm{M}$ or the $\mathrm{G}$ moieties, is done on the basis of earlier assignments of these signals in BLM performed in our $l a b^{28}$ and by other researchers. ${ }^{29}$ The assignments for all the protons in the disaccharide unit are shown in Table 1.

$\beta$-Aminoalanine $(A)$ and pyrimidinylpropionamide $(P)$ protons. Both the $\mathrm{A}$ and $\mathrm{P}$ moieties are $\mathrm{CH}_{2}-\mathrm{CH}$ spin systems based on the PEP molecular structure (Figure 1). Once the resonances for the V, B, T, H, $\mathrm{G}$ and $\mathrm{M}$ units of PEP have been assigned (vide supra), we are left with 
Table $1{ }^{1} \mathrm{H}$ data of peplomycin $5 \mathrm{~mm}$ in $\mathrm{H}_{2} \mathrm{O}^{\mathrm{a}}$ and $\mathrm{D}_{2} \mathrm{O}^{\mathrm{b}}(\mathrm{pH} \mathrm{6.5)} \mathrm{at}$ $900 \mathrm{MHz}$ and $2{ }^{\circ} \mathrm{C}$ (this study), and HOO-Co(III)-peplomycin (CoPEP) $3.74 \mathrm{~mm}$ in $50 \mathrm{~mm}$ sodium phosphate (pH 6.9), $0.1 \mathrm{~m} \mathrm{NaCl}$ aqueous solution at $500 \mathrm{MHz}$ and $2{ }^{\circ} \mathrm{C}$ (Caceres-Cortes et al. ${ }^{16}$ )

\begin{tabular}{|c|c|c|c|}
\hline \multirow[b]{2}{*}{ Proton } & \multicolumn{2}{|c|}{$\Delta \delta$ (p.p.m.) } & \multirow[b]{2}{*}{$\Delta \delta($ p.p.m.) } \\
\hline & Apo-PEP & COPEP 16 & \\
\hline $\mathrm{HC} 4 \mathrm{H}^{\mathrm{b}}$ & 7.207 & 7.62 & -0.413 \\
\hline $\mathrm{HC} 2 \mathrm{H}^{b}$ & 7.745 & 8.72 & -0.975 \\
\hline $\mathrm{HC}^{\alpha} \mathrm{H}^{\mathrm{b}}$ & 5.020 & 5.02 & 0.0 \\
\hline $\mathrm{HC}^{\beta} \mathrm{H}^{\mathrm{b}}$ & 5.230 & 5.55 & -0.320 \\
\hline $\mathrm{HNH}^{\mathrm{a}}$ & 9.488 & - & - \\
\hline $\mathrm{SC}^{\alpha} \mathrm{H}_{\mathrm{a}}{ }^{\mathrm{a}}$ & 3.325 & 3.39 & -0.065 \\
\hline $\mathrm{SC}^{\alpha} \mathrm{H}_{\mathrm{b}}{ }^{\mathrm{a}}$ & 3.392 & 3.41 & -0.018 \\
\hline $\mathrm{SC}^{\beta} \mathrm{H}_{\mathrm{a}}{ }^{\mathrm{a}}$ & 1.838 & 1.89 & -0.052 \\
\hline $\mathrm{SC}^{\beta} \mathrm{H}_{\mathrm{b}}{ }^{\mathrm{a}}$ & 1.936 & 1.99 & -0.054 \\
\hline $\mathrm{SC}^{\gamma} \mathrm{H}_{\mathrm{a}}{ }^{\mathrm{a}}$ & 2.773 & 2.84 & -0.067 \\
\hline $\mathrm{SC}^{\gamma} \mathrm{H}_{\mathrm{b}}{ }^{\mathrm{a}}$ & 2.887 & 2.95 & -0.063 \\
\hline $\mathrm{SC}^{\delta} \mathrm{H}^{\mathrm{a}}$ & 4.333 & 4.42 & -0.087 \\
\hline $\mathrm{SC}^{\delta} \mathrm{CH}_{3}{ }^{\mathrm{a}}$ & 1.592 & 1.69 & -0.098 \\
\hline $\mathrm{SN} 2 \mathrm{H}^{\mathrm{a}}$ & 7.324 & - & - \\
\hline $\mathrm{SN} 1 \mathrm{H}^{\mathrm{a}}$ & 8.724 & - & - \\
\hline $\mathrm{SC} 2,6 \mathrm{H}^{\mathrm{b}}$ & 7.334 & 7.42 & -0.086 \\
\hline $\mathrm{SC} 5,3 \mathrm{H}^{\mathrm{b}}$ & 7.239 & 7.32 & -0.081 \\
\hline $\mathrm{SC} 4 \mathrm{H}^{\mathrm{b}}$ & 7.193 & 7.24 & -0.047 \\
\hline $\mathrm{MH} 1^{\mathrm{b}}$ & 4.932 & 4.95 & -0.018 \\
\hline $\mathrm{MH} 2^{\mathrm{b}}$ & 3.994 & 4.02 & -0.026 \\
\hline$M H 3^{b}$ & 4.568 & 4.06 & 0.508 \\
\hline $\mathrm{MH} 4^{\mathrm{b}}$ & 3.730 & 3.77 & -0.04 \\
\hline $\mathrm{MH} 5^{\mathrm{b}}$ & 3.893 & 3.73 & 0.163 \\
\hline $\mathrm{MH}^{\mathrm{b}} \mathrm{a}^{\mathrm{b}}$ & 2.830 & 3.81 & -0.98 \\
\hline $\mathrm{MHC}_{\mathrm{b}}{ }^{\mathrm{b}}$ & 2.862 & 3.94 & -1.078 \\
\hline $\mathrm{MCONH}_{\mathrm{a}}{ }^{\mathrm{a}}$ & 6.075 & 6.19 & -0.115 \\
\hline $\mathrm{MCONH}_{b}{ }^{\mathrm{a}}$ & 6.469 & 6.77 & -0.301 \\
\hline $\mathrm{GH} 1^{\mathrm{b}}$ & 5.230 & 5.37 & -0.14 \\
\hline $\mathrm{GH} 2 \mathrm{~b}$ & 3.961 & 4.12 & -0.159 \\
\hline $\mathrm{GH}^{\mathrm{b}}$ & 4.037 & 4.1 & -0.063 \\
\hline $\mathrm{GH} 4{ }^{\mathrm{b}}$ & 3.774 & 3.8 & -0.026 \\
\hline $\mathrm{GH} 5^{\mathrm{b}}$ & 3.944 & 3.85 & 0.094 \\
\hline $\mathrm{GH} 6_{\mathrm{a}}^{\mathrm{b}}$ & 3.358 & 3.71 & -0.352 \\
\hline $\mathrm{GH}_{\mathrm{b}} \mathrm{b}$ & 3.487 & 3.84 & -0.353 \\
\hline $\mathrm{BC}^{\alpha} \mathrm{H}_{\mathrm{a}}^{\mathrm{a}}$ & 3.169 & 3.1 & 0.069 \\
\hline $\mathrm{BC}^{\alpha} \mathrm{H}_{\mathrm{b}}^{\mathrm{a}}$ & 3.198 & 3.28 & -0.082 \\
\hline $\mathrm{BC}^{\beta} \mathrm{H}_{2}{ }^{\mathrm{a}}$ & 3.550 & 3.665 & -0.115 \\
\hline $\mathrm{BNH}^{\mathrm{a}}$ & 8.372 & 8.58 & -0.208 \\
\hline $\mathrm{BC} 5 \mathrm{H}^{\mathrm{b}}$ & 8.065 & 8.11 & -0.045 \\
\hline $\mathrm{BC}^{\prime} \mathrm{H}^{\mathrm{b}}$ & 7.891 & 7.84 & 0.051 \\
\hline $\mathrm{VC}^{\alpha} \mathrm{H}^{\mathrm{a}}$ & 2.426 & 0.97 & 1.456 \\
\hline$V C^{\beta} H^{a}$ & 3.677 & 3.34 & 0.337 \\
\hline $\mathrm{VC}^{\gamma} \mathrm{H}^{\mathrm{a}}$ & 3.811 & 3.52 & 0.291 \\
\hline $\mathrm{VC}^{\alpha} \mathrm{CH}_{3}{ }^{\mathrm{a}}$ & 1.066 & 0.64 & 0.426 \\
\hline $\mathrm{VC}^{\gamma} \mathrm{CH}_{3}{ }^{\mathrm{a}}$ & 1.075 & 0.93 & 0.145 \\
\hline $\mathrm{VNH}^{\mathrm{a}}$ & 8.361 & 8.83 & -0.469 \\
\hline $\mathrm{TC}^{\alpha} \mathrm{H}^{\mathrm{a}}$ & 4.150 & 4.4 & -0.25 \\
\hline $\mathrm{TC}^{\beta} \mathrm{H}^{\mathrm{a}}$ & 4.029 & 4.26 & -0.231 \\
\hline $\mathrm{TCH}_{3}{ }^{\mathrm{a}}$ & 1.043 & 1.2 & -0.157 \\
\hline $\mathrm{TNH}^{\mathrm{a}}$ & 8.090 & 8.96 & -0.87 \\
\hline $\mathrm{PC}^{\beta} \mathrm{H}^{\mathrm{a}}$ & 3.904 & 5.12 & -1.216 \\
\hline$P C^{\alpha} H_{a}^{a}$ & 2.557 & 3.22 & -0.663 \\
\hline $\mathrm{PC}^{\alpha} \mathrm{H}_{\mathrm{b}}^{\mathrm{a}}$ & 2.619 & 3.52 & -0.901 \\
\hline $\mathrm{PCONH}_{\mathrm{a}}^{\mathrm{a}}$ & 6.973 & 7.33 & -0.357 \\
\hline $\mathrm{PCONH}_{b}{ }^{\mathrm{a}}$ & 7.749 & 8.06 & -0.311 \\
\hline
\end{tabular}

Table 1 Continued

\begin{tabular}{lccc}
\hline & \multicolumn{2}{c}{$\Delta \delta$ (p.p.m.) } \\
\cline { 2 - 3 } & Apo-PEP & CoPEP & \\
\hline $\mathrm{PNH}_{2}{ }^{\mathrm{a}}$ & 6.450 & 7.69 & \multicolumn{1}{c}{ (p.p.m.) } \\
$\mathrm{PCH}_{3}{ }^{\mathrm{a}}$ & 1.937 & 2.41 & -1.24 \\
$\mathrm{AC}^{\alpha} \mathrm{H}^{\mathrm{a}}$ & 3.903 & 3.43 & -0.473 \\
$\mathrm{AC}^{\beta} \mathrm{H}_{\mathrm{a}}{ }^{\mathrm{a}}$ & 2.557 & 2.74 & 0.473 \\
$\mathrm{AC}^{\beta} \mathrm{H}_{\mathrm{b}}{ }^{\mathrm{a}}$ & 2.619 & 3.23 & -0.183 \\
$\mathrm{ACONH}_{\mathrm{a}}{ }^{\mathrm{a}}$ & 6.973 & 7.07 & -0.611 \\
$\mathrm{ACONH}_{\mathrm{b}}{ }^{\mathrm{a}}$ & 7.749 & 7.83 & -0.097 \\
$\mathrm{ANH}_{\mathrm{a}}{ }^{a}$ & 6.942 & 5.93 & -0.081 \\
$\mathrm{ANH}_{\mathrm{b}}{ }^{\mathrm{a}}$ & 7.688 & 6.58 & 1.012 \\
\hline
\end{tabular}

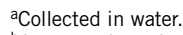

bollected in $\mathrm{D}_{2} \mathrm{O}$.

a set of four signals that are SECSY and TOCSY (Figure 2) connected with the patterns 3.904 to 2.547 p.p.m. and 3.903 to 2.611 p.p.m. The only candidates left for the assignments of these signals are the A and $\mathrm{P}$ residues in the PEP molecule. These two pairs of signals are attributed to the $\mathrm{PC}^{\beta} \mathrm{H}$ and $\mathrm{PC}^{\alpha} \mathrm{H}_{2}(3.904 ; 2.557,2.619)$ p.p.m. and $\mathrm{AC}^{\alpha} \mathrm{H}$ and $\mathrm{AC}^{\beta} \mathrm{H}_{2}(3.903 ; 2.557,2.619)$ p.p.m. protons based on the assignments of the ${ }^{13} \mathrm{C}$ signals of the PEP molecule performed by Naganawa et al. ${ }^{30}$ The assignments of these signals are confirmed by their NOESY (Figure 5a) connectivities to the $\mathrm{NH}_{2}$ protons in the $\mathrm{A}$ and $\mathrm{P}$ moieties (vide supra).

Exchangeable NH protons. The amide proton resonances of the $\mathrm{H}, \mathrm{S}$, $\mathrm{B}, \mathrm{V}$ and $\mathrm{T}$ units in PEP can be assigned, as the resonances of the nonexchangeable protons of these spin systems have been already identified (vide supra). Figure 5b shows the TOCSY connectivities between the SN1H (8.724 p.p.m.), BNH (8.372 p.p.m.), VNH (8.361 p.p.m.) and TNH (8.090 p.p.m.) and other members of the corresponding spin systems. The $\mathrm{NH}$ resonance of the $\mathrm{H}$ moiety is located further downfield (9.488 p.p.m.) and it is identified based on its TOCSY connectivity to the $\mathrm{HC}^{\beta} \mathrm{H}$ proton (Figure 5 inset). A very downfield position for this $\mathrm{NH}$ proton is also found for other members of the BLM family. ${ }^{28,29}$ Confirmation of the assignments of the $\mathrm{HC}^{\alpha} \mathrm{H}$, $\mathrm{HC}^{\beta} \mathrm{H}$ and $\mathrm{HNH}$ is obtained through the connectivities displayed by them in the TOCSY spectrum collected in DMSO (Supplementary Figure S1).

The $\mathrm{SN} 2 \mathrm{H}$ proton (Figure 1) is located at 7.324 p.p.m. Its connectivities to the $\mathrm{SC}^{\delta} \mathrm{H}$ and $\mathrm{SC}^{\gamma} \mathrm{H}_{2}$ are displayed in the NOESY spectrum in Figure 5a. This proton has not been reported in earlier assignments of the PEP molecule. ${ }^{16}$

Exchangeable $\mathrm{NH}_{2}$ protons. The PEP molecule exhibits five $\mathrm{NH}_{2}$ groups (Figure 1) located in the $\mathrm{P}, \mathrm{A}$ and $\mathrm{M}$ residues. The most upfield-shifted $\mathrm{NH}_{2}$ signals are observed at 6.075 and 6.469 p.p.m. These very broad signals are assigned to the $\mathrm{CONH}_{2}$ protons of the $\mathrm{M}$ residue based on earlier NMR studies of various members of the BLM family. ${ }^{16,28,29}$ The $\mathrm{CONH}_{2}$ groups in the $\mathrm{A}$ and $\mathrm{P}$ residues are assigned to the pair $(6.973,7.749)$ p.p.m. on the basis of their NOESY connectivities (Figure 5a) to the other protons in the $\mathrm{P}$ and $\mathrm{A}$ spin systems. These $\mathrm{CONH}_{2}$ groups exhibit strong overlap at $\mathrm{pH} 6.5$, even on the NOESY and TOCSY spectra acquired at $900 \mathrm{MHz}$, which prevents their individual assignments. The other $\mathrm{NH}_{2}$ group in the A moiety is located at $(6.942,7.688)$ p.p.m. (Figure 5a). The $\mathrm{PNH}_{2}$ protons are identified at 6.450 p.p.m. through their NOESY connections to the $\mathrm{PCH}_{3}$ (1.937 p.p.m.) group. 

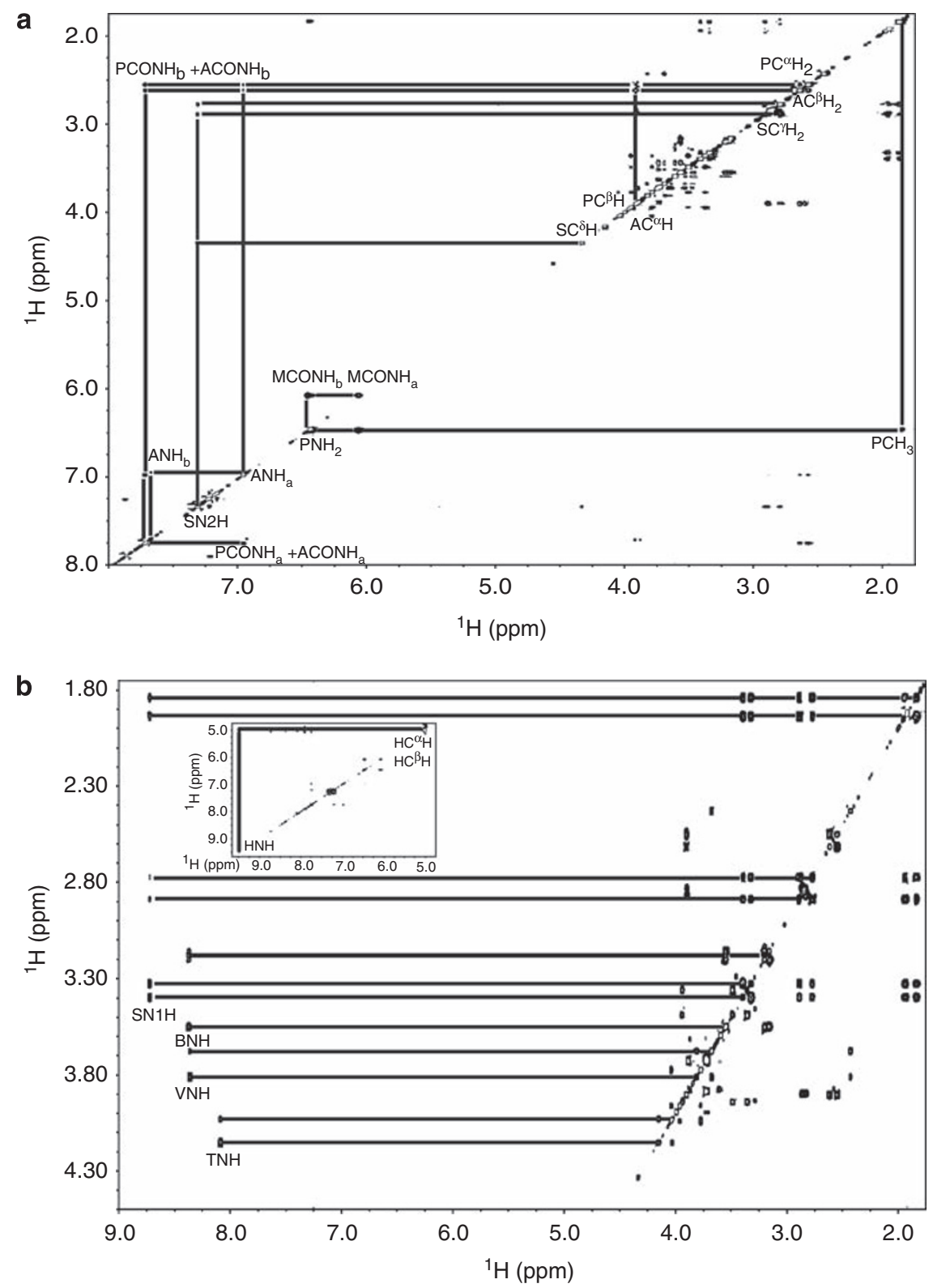

Figure 5 (a) The $1.75-8.00$ p.p.m. region of the $900 \mathrm{MHz}$ NOESY spectrum ( $150 \mathrm{~ms}$ mixing time) at $2{ }^{\circ} \mathrm{C}$, pH 6.5 of a $5 \mathrm{~mm} \mathrm{PEP}$ sample $90 \% \mathrm{H}_{2} \mathrm{O} / 10 \%$ $\mathrm{D}_{2} \mathrm{O}$ showing the assignments of the $\mathrm{P}\left(\mathrm{CONH}_{2}, \mathrm{NH}_{2}, \mathrm{CH}_{3}\right), \mathrm{A}\left(\mathrm{CONH}_{2}, \mathrm{NH}_{2}\right), \mathrm{MCONH}_{2}$ and $\mathrm{SN} 2 \mathrm{H}$ protons. (b) The 1.75-9.00 p.p.m. region of the same spectrum showing the assignments of the $\mathrm{SN} 1 \mathrm{H}, \mathrm{VNH}, \mathrm{BHN}$ and TNH protons. Inset: the 4.75-9.75 p.p.m. region of the $900 \mathrm{MHz}$ TOCSY spectrum (40 ms mixing time) $2{ }^{\circ} \mathrm{C}$, pH 6.5 of a $5 \mathrm{~mm}$ PEP sample $90 \% \mathrm{H}_{2} \mathrm{O} / 10 \% \mathrm{D}_{2} \mathrm{O}$ showing the assignments of the HNH proton.

\section{Structural exploration of apo-PEP}

The structure of apo-PEP was explored. In order to do so, we took the structure of HOO-Co(III)PEP published by Caceres-Cortes et al. ${ }^{16}$ as our initial structure. The HOO-Co(III) segment of the initial structure was eliminated and the resulting structure was minimized and submitted to simulated annealing. The results of the calculation aforementioned are presented as Supplementary Figure S2 and Table 2. The results of the calculations indicate that once the HOO-Co(III) segment of the HOO-Co(III)-PEP molecule is released, apo-PEP starts evolving under minimization and simulated annealing towards a structure that departs from the initial conformation towards a more extended structure. The T-V-H-P-A-G-M segment of apo-PEP is more open and these residues tend to separate from each other in the absence of the metal center. These facts agree with the results shown in
Table 2 RMSD calculated residue by residue after overlap of HOO-Co(III)PEP ${ }^{16}$ and apo-PEP

\begin{tabular}{lc}
\hline Residues & $R M S D$ \\
\hline B-Aminoalanine (A) & 1.927 \\
Pyrimidinylpropionamide (P) & 2.290 \\
$\beta$-Hydroxyhistidine (H) & 1.348 \\
Gulose (G) & 1.198 \\
Mannose (M) & 2.092 \\
Methylvalerate (V) & 1.476 \\
Threonine (T) & 1.032 \\
Bithiazole (B) & 0.959 \\
Sulfonium (S) & 0.419
\end{tabular}

Abbreviation: RMSD, root mean square deviation. 
Table 1 , where the $\Delta \delta$ exhibited by the $\mathrm{T}-\mathrm{V}-\mathrm{H}-\mathrm{P}-\mathrm{A}-\mathrm{G}-\mathrm{M}$ are those of highest magnitudes. The B-S segment in HOO-Co(III)-PEP and apoPEP overlap relatively well, as predicted also in Table 1 . In order to emphasize the arguments explained above, the root mean square deviation (RMSD) between the HOO-Co(III)-PEP and our apo-PEP structures were calculated residue by residue (Table 2). As shown in this table, the smallest RMSD are exhibited by the B-S segment of PEP.

\section{DISCUSSION}

The ${ }^{1} \mathrm{H}-\mathrm{NMR}$ assignments for the PEP molecule are presented in this investigation as the initial stage of an NMR study of the solution conformation and dynamics of PEP and its derivatives, and of the structural interactions with their target DNA. PEP spectra collected at $900 \mathrm{MHz}$, for the first time, have facilitated the unambiguous assignments of the PEP protons.

Caceres-Cortes et al. have determined the solution structures of HOO-Co(III)-PEP (CoPEP) and HOO-Co(III)-deglyco-PEP through NMR and molecular dynamics. ${ }^{16}$ The differences between the chemical shifts displayed by the ${ }^{1} \mathrm{H}$ signals in CoPEP and those in apo-PEP $(\Delta \delta)$ are shown in Table 1 , with the $\mathrm{A}, \mathrm{P}, \mathrm{H}, \mathrm{T}, \mathrm{M}, \mathrm{G}$ and $\mathrm{V}$ residues exhibiting the largest $\Delta \delta$ s. These results can be understood after close examination of the solution structure of CoPEP. ${ }^{16}$ In CoPEP the PN3, $\mathrm{HNH}, \mathrm{HN} 1, \mathrm{ANH}$ and $\mathrm{MCONH}_{2}$ nitrogens are coordinated to the metal center, which puts them in close proximity to each other and explains the non-trivial NOEs found, connecting them through space in this metallo-PEP such as: $\mathrm{ANH}-\mathrm{HC} 2 \mathrm{H}, \mathrm{AC}^{\beta} \mathrm{H}_{\mathrm{a}}-\mathrm{P}\left(\mathrm{C}^{\alpha} \mathrm{H}_{\mathrm{a}}, \mathrm{C}^{\beta} \mathrm{H}\right)$, ANH-PC ${ }^{\beta} \mathrm{H}, \quad \mathrm{HC} 2 \mathrm{H}-\mathrm{A}\left(\mathrm{C}^{\beta} \mathrm{H}_{\mathrm{a}}, \quad \mathrm{C}^{\beta} \mathrm{H}_{\mathrm{b}}\right), \quad \mathrm{HC} 2 \mathrm{H}-\mathrm{P}\left(\mathrm{C}^{\alpha} \mathrm{H}_{\mathrm{a}}, \quad \mathrm{C}^{\beta} \mathrm{H}\right)$, $\mathrm{HC}^{\beta} \mathrm{H}-\mathrm{G}\left(\mathrm{H} 1, \mathrm{H} 2, \mathrm{H} 5, \mathrm{H} 6_{\mathrm{a}}, \mathrm{H} 6_{\mathrm{b}}\right), \mathrm{HC}^{\alpha} \mathrm{H}-\mathrm{G}(\mathrm{H} 1, \mathrm{H} 2)$ and $\mathrm{GH} 1-$ $\mathrm{MH}_{\mathrm{a}} \cdot{ }^{16}$ In apo-PEP, only trivial NOEs are displayed by the P, A, H, G, $\mathrm{V}, \mathrm{T}$ and $\mathrm{M}$ moieties indicating their extended conformation. The ${ }^{1} \mathrm{H}$ $\Delta \delta$ s found between these moieties in CoPEP and apo-PEP suggest that the closeness to the coordination cage due to coordination of the A, P, $\mathrm{H}$ and $\mathrm{M}$ units in CoPEP exposes them to local magnetic fields different from those found in the extended apo-PEP (ring currents generated by the $\mathrm{P}$ and $\mathrm{H}$ rings). Additionally, different conformations of the coordinated moieties are expected in CoPEP when compared with apo-PEP and also contribute to generate the $\Delta \delta$ s in Table 1 . Although $\mathrm{G}$ is not coordinated to the Co(III) ion in CoPEP, examination of the solution structure of this molecule indicates that this PEP residue is also located close to the metal coordination site due to metal ligation by the $\mathrm{MNH}_{2}$ nitrogen.

The folding of the $\mathrm{B}-\mathrm{S}$ segment underneath the equatorial plane of the metal in CoPEP brings the $\mathrm{V}$ and $\mathrm{T}$ residues close to the coordination cage and generates non-trivial NOEs such as $\mathrm{HC} 2 \mathrm{H}-$ $\mathrm{V}\left(\mathrm{C}^{\alpha} \mathrm{H}, \mathrm{C}^{\alpha} \mathrm{CH}_{3}\right), \mathrm{HC} 4 \mathrm{H}-\mathrm{V}\left(\mathrm{C}^{\alpha} \mathrm{H}, \mathrm{C}^{\alpha} \mathrm{CH}_{3}\right)$ and $\mathrm{HC} 2 \mathrm{H}-\mathrm{T}\left(\mathrm{C}^{\alpha} \mathrm{H}\right.$, $\left.\mathrm{C}^{\beta} \mathrm{H}\right)$. Additionally, the $\mathrm{V}-\mathrm{T}$ fragment is reported to be extensively folded in CoPEP. None of these NOEs were detected by us in our analysis of the $900 \mathrm{MHz}$ NOESY spectra of apo-PEP, again pointing towards an extended conformation of apo-PEP. The different magnetic environments experienced by $\mathrm{T}$ and $\mathrm{V}$ in apo-PEP and CoPEP and their different conformations due to folding in CoPEP generate the $\Delta \delta$ s calculated for these residues in Table 1.

The smallest $\Delta \delta$ s in Table 1 are those calculated for the S-B unit, indicating that this PEP segment is the least affected upon metal coordination. Non-trivial NOEs such as $\mathrm{PCH}_{3}-\mathrm{BC} 5 \mathrm{H}, \mathrm{VC}^{\beta} \mathrm{H}-\mathrm{BC} 5^{\prime} \mathrm{H}$ and $\mathrm{VC}^{\gamma} \mathrm{CH}_{3}-\mathrm{BC} 5^{\prime} \mathrm{H}$ reported for CoPEP, ${ }^{16}$ connecting the $\mathrm{P}, \mathrm{V}$ and $\mathrm{B}$ residues, are the indicators of the folding of the $\mathrm{B}-\mathrm{S}$ unit underneath the equatorial plane of the metal. Therefore, the ${ }^{1} \mathrm{H} \delta$ s of the $\mathrm{B}-\mathrm{S}$ segment should be affected by closeness to the coordination cage of the metal in CoPEP. In apo-PEP, only trivial NOEs are found for the $\mathrm{P}, \mathrm{V}$ and $\mathrm{B}$ moieties, suggesting that the terminal unit of PEP is not folded close to the $\mathrm{P}$ and $\mathrm{V}$ residues. The difference in the magnetic environment experienced by the $\mathrm{B}-\mathrm{S}$ unit in CoPEP and metal-free PEP is likely to cause the $\Delta \delta$ s reported in Table 1 . Although close to the metal coordination cage, the B-S unit in CoPEP displays an extended conformation. Measurements of the relaxation times $\left(\mathrm{T}_{1}\right)$ of the protons in the $\mathrm{B}$ and $\mathrm{S}$ residues performed in $\mathrm{CoPEP}^{16}$ allowed the characterization of the $\mathrm{B}-\mathrm{S}$ segment as very flexible, relative to the metal-binding domain. A similar situation is expected for the terminal segment of PEP in its metal-free form. The conformational freedom of the $\mathrm{B}-\mathrm{S}$ unit in both CoPEP and apo-PEP makes their ${ }^{1} \mathrm{H} \delta$ s more similar to each other when compared with those of the other PEP moieties. This situation is expected to change in the presence of DNA. In summary, our NMR results indicate that the overall structure of apo-PEP is extended in solution, but exhibiting a conformational freedom of the B-S unit similar to that of CoPEP. ${ }^{16}$ Although a calculation has been discussed here, its goal is only to show the tendency of apo-PEP after HOO-Co(III) release. The reason is that the HOO-Co(III)-PEP molecule has already been submitted to extensive minimization and annealing processes before arriving to the final structure published by Caceres-Cortes et al. Releasing the HOO$\mathrm{Co}$ (III) segment and allowing minimization and extra annealing shows the correct tendency of apo-PEP to 'open up', relative to its initial more compact structure, once the T-V-H-P-A-G-M loses the structural factor that produces its folding. However, no drastic structural changes are expected, in the absence of non-trivial NOEs that can take apo-PEP to a very different conformation, as HOOCo(III)-PEP was already in its energy minimum. The RMSD calculated for each residue in apo-PEP (Table 2) agree very well with the NMR data presented in this study, evincing the compatibility between experiment and simulation.

Because of the structural differences in molecular structures regarding the DNA binding domains in BLM and PEP, differences between these two anticancer agents are expected to be found in our future studies of the interactions of their $\mathrm{Fe}(\mathrm{II})$ and $\mathrm{Cu}(\mathrm{I})$ complexes with DNA. These differences could help explain the reported dissimilarities in activity toward DNA cleavage displayed by these two drugs. ${ }^{11,12}$

\section{CONFLICT OF INTEREST}

The authors declare no conflict of interest.

\section{ACKNOWLEDGEMENTS}

This work was supported by the University of Wyoming start-up funds. NMR experiments collected at $900 \mathrm{MHz}$ were conducted at the Rocky Mountain 900 Facility (grant number NIHGM68928). NMR experiments collected at $400 \mathrm{MHz}$ were conducted at the NMR facility of the Chemistry Department at the University of Wyoming. We thank Nippon Kayaku (Tokyo, Japan) for kindly providing the PEP employed in our studies. Our gratitude also goes to Dr Bruce A Johnson (Merck Research Laboratories, Rahway, NJ) and Dr Frank Delaglio (Software Science Consultant, North Potomac, MD) for kindly providing the software NMRPipe and NMRView, respectively. This publication was made possible by NIH Grant \# P20 RR016474 from the INBRE Program of the National Center for Research Resources. Its contents are solely the responsibility of the authors and do not necessarily represent the official views of NIH.

1 Umezawa, H., Maeda, K., Takeuchi, T. \& Okami, Y. New antibiotics bleomycin A and B. J. Antibiot. 19, 200-209 (1966).

2 Bennett, J. M. \& Reich, S. D. Bleomycin. Ann. Intern. Med. 90, 945-948 (1979).

3 Carlson, R. W., Sikic, B. I., Turbow, M. M. \& Ballon, S. C. Combination cisplatin, vinblastine, and bleomycin chemotherapy (PVB) for malignant germ-cell tumors of the ovary. J. Clin. Oncol. 1, 645-651 (1983). 
4 Bleomycin Chemotherapy (eds Sikic, B. I., Rozencweig, M. \& Carter S. K.) (Academic Press, Orlando, FL, 1985).

5 Einhorn, L. H. \& Donohue, J. Cis-diamminedichloroplatinum, vinblastine, and bleomycin combination chemotherapy in disseminated testicular cancer. Ann. Intern. Med. 87, 293-298 (1977).

6 Umezawa, H. in Bleomycin: Chemical, Biochemical and Biological Aspects (ed Hecht, S. M.) 24-36 (Springer, New York, 1977).

7 Claussen, C. A. \& Long, E. C. Nucleic acid recognition by metal complexes of bleomycin. Chem. Rev. 99, 2797-2816 (1999).

8 Ekimoto, H., Katsutoshi, T., Matsuda, A., Takita, T. \& Umezawa, H. Lipid-peroxidation by bleomycin-iron complexes in vitro. J. Antibiot. 38, 1077-1082 (1985).

9 Swendsen, C. L., Skita, V. \& Thrall, R. S. Alterations in surfactant neutral lipid composition during the development of bleomycin-induced pulmonary fibrosis. Biochim. Biophys. Acta. 1301, 90-96 (1996).

10 Hecht, S. M. in Bleomycin: Chemical, Biochemical and Biological Aspects (ed Hecht, S. M.). 8-9 (Springer-Verlag, New York, 1979).

11 Tanaka, W. \& Takita, T. Pepleomycin-2nd generation bleomycin chemically derived from bleomycin $A_{2}$. Heterocycles 13, 469-476 (1979).

12 Oka, S. A review of clinical-studies of pepleomycin. Recent Results Cancer Res. 74, 163-171 (1980).

13 Sugiura, Y. Bleomycin-iron complexes-electron-spin resonance study, ligand effect, and implication for action mechanism. J. Am. Chem. Soc. 102, 5208-5215 (1980).

14 Petering, D. H., Mao, Q., Li, W., DeRose, E. \& Antholine, W. E. in Metal lons in Biological Systems (eds Sigel A. \& Sigel, H) vol. 33 619-646 (Marcel Dekker, New York, 1996).

15 Stubbe, J. \& Kozarich, J. W. Mechanisms of bleomycin-induced DNA-degradation. Chem. Rev. 87, 1107-1136 (1987).

16 Caceres-Cortes, J., Sugiyama, H., Ikudome, K., Saito, I. \& Wang, A. Structures of cobalt(III)-pepleomycin and cobalt(III)-deglycopepleomycin (green forms) determined by NMR studies. Eur. J. Biochem. 244, 818-828 (1997).

17 Wasinger, E. C., Zaleski, K. L., Hedman, B., Hodgson, K. O. \& Solomon, E. I. $\mathrm{X}$-ray absorption spectroscopic investigation of $\mathrm{Fe}(\mathrm{II})$-peplomycin and peplomycin derivatives: the effect of axial ligation on Fe-pyrimidine back-bonding. J. Biol. Inorg. Chem. 7, 157-164 (2002).

18 liyama, T., Chikira, M., Oyoshi, T. \& Sugiyama, H. Deglyco-peplomycin metal complexes on DNA fibers: a role of the sugar moiety for the stability and the orientation of the complexes. J. Biol. Inorg. Chem. 8, 135-140 (2003).

19 Delaglio, F. et al. NMRPipe-a multidimensional spectral processing system based on Unix pipes. J. Biomol. NMR 6, 277-293 (1995).

20 Johnson, B. A. \& Blevins, R. A. NMR view-a computer-program for the visualization and analysis of NMR data. J. Biomol. NMR 4, 603-614 (1994).

21 Braunschweiler, L. \& Ernst, R. R. Coherence transfer by isotropic mixing-application to proton correlation spectroscopy. J. Magn Reson. 53, 521-528 (1983).

22 Bax, A. \& Davis, D. G. MLEV-17-based two-dimensional homonuclear magnetization transfer spectroscopy. J. Magn. Reson. 65, 355-360 (1985).

23 Jeener, J., Meier, B. H., Bachmann, P. \& Ernst, R. R. Investigation of exchange processes by 2-dimensional NMR-spectroscopy. J. Chem. Phys. 71, 4546-4553 (1979).

24 Nagayama, K., Wüthrich, K. \& Ernst, R. R. 2-dimensional spin-echo correlated spectroscopy (SECSY) for H1-NMR studies of biological macromolecules. Biochem. Biophys. Res. Commun. 90, 305-311 (1979).

25 Nagayama, K., Kumar, A., Wüthrich, K. \& Ernst, R. R. Experimental-techniques of two-dimensional correlated spectroscopy. J. Magn. Reson. 40, 321-334 (1980).

26 Rance, M. et al. Improved spectral resolution in COSY H1-NMR spectra of proteins via double quantum filtering. Biochem. Biophys. Res. Commun. 117, 479-485 (1983).

27 Bax, A. \& Subramanian, S. Sensitivity-enhanced two-dimensional heteronuclear shift correlation NMR-spectroscopy. J. Magn. Reson. 67, 565-569 (1986).

28 Lehmann, T. E. Structural study of Cu(I)BLM. J. Biol. Inorg. Chem. 9, 323-334 (2004).

29 Haasnoot, C. A. G., Pandit, U. K., Kruk, C. \& Hilbers, C. W. Complete assignment of the $500 \mathrm{MHz} 1 \mathrm{H}-\mathrm{NMR}$ spectra of bleomycin $\mathrm{A} 2$ in $\mathrm{H}_{2} \mathrm{O}$ and $\mathrm{D}_{2} \mathrm{O}$ solution by means of twodimensional NMR-spectroscopy. J. Biomol. Struc. Dyn 2, 449-467 (1984).

30 Naganawa, H., Kadokura, Y., Muraoka, Y., Nakatani, T. \& Takita, T. C-13 NMR assignment of peplomycin. J. Antibiot. 42, 633-636 (1989).

Supplementary Information accompanies the paper on The Journal of Antibiotics website (http://www.nature.com/ja) 